\title{
Anatomical studies on the leaf and stem of Tinospora formanii Udayan \& Pradeep (Menispermaceae), an endemic species to Southern Western Ghats, Kerala, India
}

\author{
R. Patturaj', S. Noorunnisa Begum*, K. Ravikumar', P. Sheema Dharmapal ${ }^{2}$, \\ P.S. Udayan ${ }^{2}$
}

'National Herbarium of Medicinal Resources, Center for Conservation of Natural Resources, The University of TransDisciplinary Health Sciences and Technology (TDU), Bangalore - 560064, Karnataka, India, ${ }^{2}$ Research Centre \& P. G. Department of Botany, Sree Krishna College, Ariyannur, Guruvayur, Thrissur, Kerala, India

Received: September 03, 2020 Revised: May 29, 2021 Accepted: June 07, 2021 Published: July 23, 2021

*Corresponding Author: S. Noorunnisa Begum E-mail: noorunnisa.begum@ tdu.edu.in

\section{ABSTRACT}

The anatomical studies on leaf and stem of T. formanii Udayan and Pradeep an endemic species to Southern Western Ghats, Kerala, India was carried out focusing on its macroscopic, microscopic, maceration along with organoleptic evaluation. Distinguishing characters of the stem revealed the presence of calcium oxalate crystals, simple and compound starch grains and pitted lignified fibers. Leaf anatomy showed the anomocytic and paracytic stomata, pitted lignified fibers, spiral vessels, non-glandular small trichomes, $\mathrm{C}$ or half-moon shaped vascular bundle, surrounded with sclerenchymatous tissues and rosette and prism shaped calcium oxalate crystals. Whereas, maceration studies revealed the presence of spiral and scalar form vessel, fibers, calcium oxalate crystals, simple starch grains. These anatomical studies are vital in the present-day trade scenario not only helpful in the proper identification of the genuine materials in use but also to distinguish different species of Tinospora, where the stem and leaf are often admixed with other species of Tinospora in the crude drug markets.

KEYWORDS: Anatomical studies; Leaf; Stem; Endemic species

\section{INTRODUCTION}

Medicinal plants play a pivotal role in the traditional systems of medicines (Saleem et al., 2001). All traditional systems of medicine mainly focus their attention on the natural products that help the human race to sustain longer and stronger life. Among the world population, $80 \%$ of those belongs to developing countries still rely on traditional medicine because of its efficacy, cultural acceptability and lesser side effects (Shrestha \& Dhillion, 2003). Lack of systematic written proof and poor-quality control are major cause in less acceptance of the use of alternative medicine. Therefore, there is an immediate need to have standards for all medicinal plants. For this there are several technique and methodology and pharmacognostic and phytochemical studies is one of such tools. Such efforts will be useful in developing standardization of the identity of the plant. Correct characterization and quality assurance of the plant material is an essential step to ensure reproducible quality of herbal medicine which will help to justify its safety and efficacy (Ahmed et al., 2006; Odugbemi 2008). For this purpose, anatomical studies of Tinospora formanii are carried out in this study.

In the present study, the focus was on one of the endemic plant species in Kerala, T. formanii. The genus Tinospora belonging to the family Menispermaceae has about 32 species distributed in Tropical Africa, Madagascar, Asia to Australia and Pacific Islands (Rohwer \& Bittrich 1990; Mabberley 1997). In India, the genus is represented by 4 species. Among them, 2 species namely, T. cordifolia (Willd.) Miers. ex Hook. f. \& Thomson and T. sinensis (Lour.) Merr. are known to occur in southern India. The remaining two species T. crispa (L.) Miers. ex Hook. f. and Thomson and T. glabra (Burm. f.) Merr. are reported from North-East India and Andaman Islands (Pramanik \& Gangopadhyay 1993).

Copyright: (C) The authors. This article is open access and licensed under the terms of the Creative Commons Attribution License (http://creativecommons.org/licenses/by/4.0/) which permits unrestricted, use, distribution and reproduction in any medium, or format for any purpose, even commercially provided the work is properly cited. Attribution — You must give appropriate credit, provide a link to the license, and indicate if changes were made. 
T. formanii Udayan and Pradeep, a new species described recently from the Western Ghats of Thrissur district, Kerala, southern India (Udayan et al., 2009). T. formanii is a woody dioecious climber growing at an altitude of 500-650 m and is endemic to Kerala. Leaves are ovate to elliptic-lanceolate, coriaceous and glabrous with reticulation more prominent on the lower surface. Female inflorescence is greenish-yellow, glabrous, stout compound elongated pseudo-racemes with six petals. Drupes are globose and red when mature. It differs from T. crispa by the absence of tuberculate stems and the glandular patches in the basal nerve axils of the leaves, and in having six petals as opposed to the three of T. crispa (Sheema et al., 2017).

\section{MATERIALS AND METHODS}

\section{Sample Collection}

The fresh plant specimens are used in the present study were collected from Vellanimala forest (Latitude $10^{\circ} 34^{\prime} \mathrm{N}$ and Longitude $76^{\circ} 19^{\prime} \mathrm{E}$ ) in Thrissur District, Western Ghats of Kerala in Southern India. Plant specimens were identified and herbarium samples present in herbarium of (Udayan et al. 03374 B CAL, CALI and MH, Female Plant).

\section{Macro and Microscopic Studies}

Macroscopic and organoleptic characters such as colour, size, odour and taste were documented. Fresh materials of petiole, leaf and stems are cut into $1-2 \mathrm{~cm}$ small pieces, fixed with Formalin acetic alcohol (FAA) and take freehand sections stained with safranin and TBO mounded with glycerin. Stomatal number and index were studied in the leaves. All the photomicrographs were taken using Olympus CX 33 light microscope.

\section{Histochemical Studies}

Fresh materials of mature stems were cut into small pieces and freehand sectioning was done. Detailed identification characters were noted with or without staining procedures (Krishnamurthy, 1988). Histochemical studies on stem were carried out using lignin Potassium iodide-iodine-sulphuric acid method (Chamberlain, 1924), Starch Iodine-Potassium-iodide reaction (Johansen, 1940), total proteins Fast green method (Ruthmann, 1970).

\section{Macerations Techniques}

The fresh material of the mature stems was cut into small slices or slivers about 300 micrometers thick. Then soaked in macerated solution of equal parts of $10 \%$ aqueous nitric acid and $10 \%$ aqueous chromic acid. This solution kept into the room temperature in 24 hours (Jeffery, 1917).

\section{RESULT}

\section{Organoleptic Evaluation}

The organoleptic characters of leaves showed the light green appearance from both sides having small elongated glands. The leaf powder was yellowish green in colour, soft in texture, with unpleasant odour and light bitter in taste. The stem was green in nature (soft) having light brown colour from the basal side.

\section{Macroscopic Characters}

The species is restricted to the moist deciduous forest at an altitude of $550 \mathrm{~m}$ at Vellanimala forest, Thrissur district of Kerala. It is rare and sparsely distributed only 3 mature plants were noted in the area along with Tinospora sinensis. T. formanii is a woody dioecious climber, with pale yellowish watery sap when cut; bark smooth, shining, papery, peeling off into scales, with prominent leaf-scars. Stems up to $4 \mathrm{~cm}$ thick, with several prominent concentric rings, lenticellate. Leaves (Figure 1, Table 1) alternate, ovate to elliptic-lanceolate, 6-14 x 4-8 cm, coriaceous, glabrous, acuminate at apex, cordate at base, entire; 3-nerved basally, lateral nerves intra-marginal, running to tip of lamina, distinctly looping along the margin; lateral nerves 3-4 pairs, reticulation more prominent on lower surface, glandular patches present in basal nerve axils; petioles slender, slightly swollen and geniculate at base, 5-12 cm long, often drying blackish at least at the swollen base and near the lamina. The sufficient number of female flowers and fruits could be collected only after two years of continuous field observations. This liana reaches the top canopy of host trees such as Diospyros

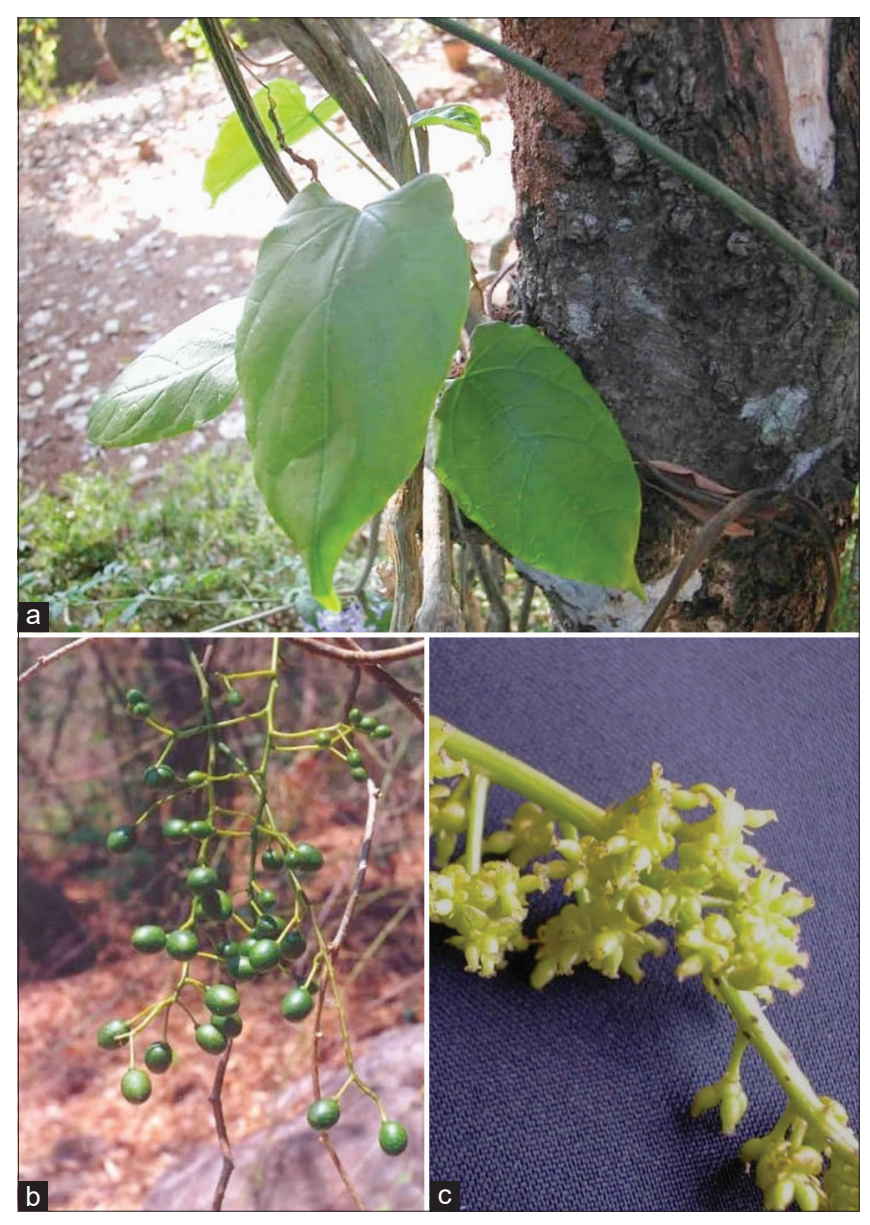

Figure 1: Field images of T. formanii Udayan \& Pradeep. a. Habit, b. Fruits and c. Flowers. 
crumenata Thw. (Ebenaceae); Drypetes oblongifolia (Bedd.) Airy Shaw (Euphorbiaceae) and Bambusa bambos (L.) Voss (Bambusaceae). This plant while flowering usually devoid of leaves, (January - May) and soon after flowering and fruiting, leaves emerge in the early monsoon (June) and thus the leaves are produced gregariously. Only 3 female plants could be located in the entire study area without male plants.

\section{Microscopic Characters}

\section{Petiole}

Transverse section of the petiole shows (Figure 2, Table 1) the epidermis, ground tissue, vascular bundles and centrally located parenchymatous tissue. Outermost single layered epidermis consisting of narrow shaped, compactly arranged thick walled cuticle. Beneath the epidermis 4-6 layer of collenchyma tissue consisting of compactly arranged and thin-walled collenchyma cells. Beneath cortex there is 3-4 layered pericycle fibers. These thick wall cells are covered with a cap like structure of the vascular bundles and prism-shaped calcium oxalate crystals. Vascular bundles are 6-8 number of cells, collateral, open and endarch arranged in a ring. Metaxylem towards the sclerenchymatous region and protoxylem towards the parenchymatous region. Medullary ray single layered parenchymatous cells are interrupted to the xylem region.

\section{Leaf}

Transverse Section of T. formanii leaf passing through the midrib (Figure 2) shows slightly convex nature, however non-glandular small hairs are present in abaxial side veins only. The adaxial and abaxial side epidermis is single layered rectangular shaped and compactly arranged, covered with thin wall cuticles. The lamina is a dorsiventral structure made up of mesophyll tissues which can be divided into adaxial side palisade and abaxial side spongy tissues. The mesophyll cells mostly appear in the chlorophyll pigments. Palisade parenchymatous cells are single layered, columnar cells. The spongy cells are loosely arranged. Midrib vascular bundles are collateral and open. Xylem is more than 10 numbers of the cells. Xylem rays are present in the fibers and rosette calcium oxalate crystals. The $\mathrm{C}$ or half-moon shaped structure of sclerenchyma cells covered with vascular bundles. This thick-wall cell is present in the square and prism-shaped calcium oxalate crystals. The phloem arrangement is towards the midrib abaxial side. Anomocytic and paracytic stomata are present on both sides of the leaves. This stoma surrounded by four subsidiary cells, which are indistinguishable in size and shape.

\section{Stem}

Transverse Section of the stem is circular in outline (Figure 3, Table 1) with cork, cortex and stellar region. The cork comprises of an outer zone of thick-walled reddishbrown compressed cells and an inner zone of thin-walled colourless, tangentially arranged cells. The cork tissue is broken at some places due to lenticels. The outer zone of
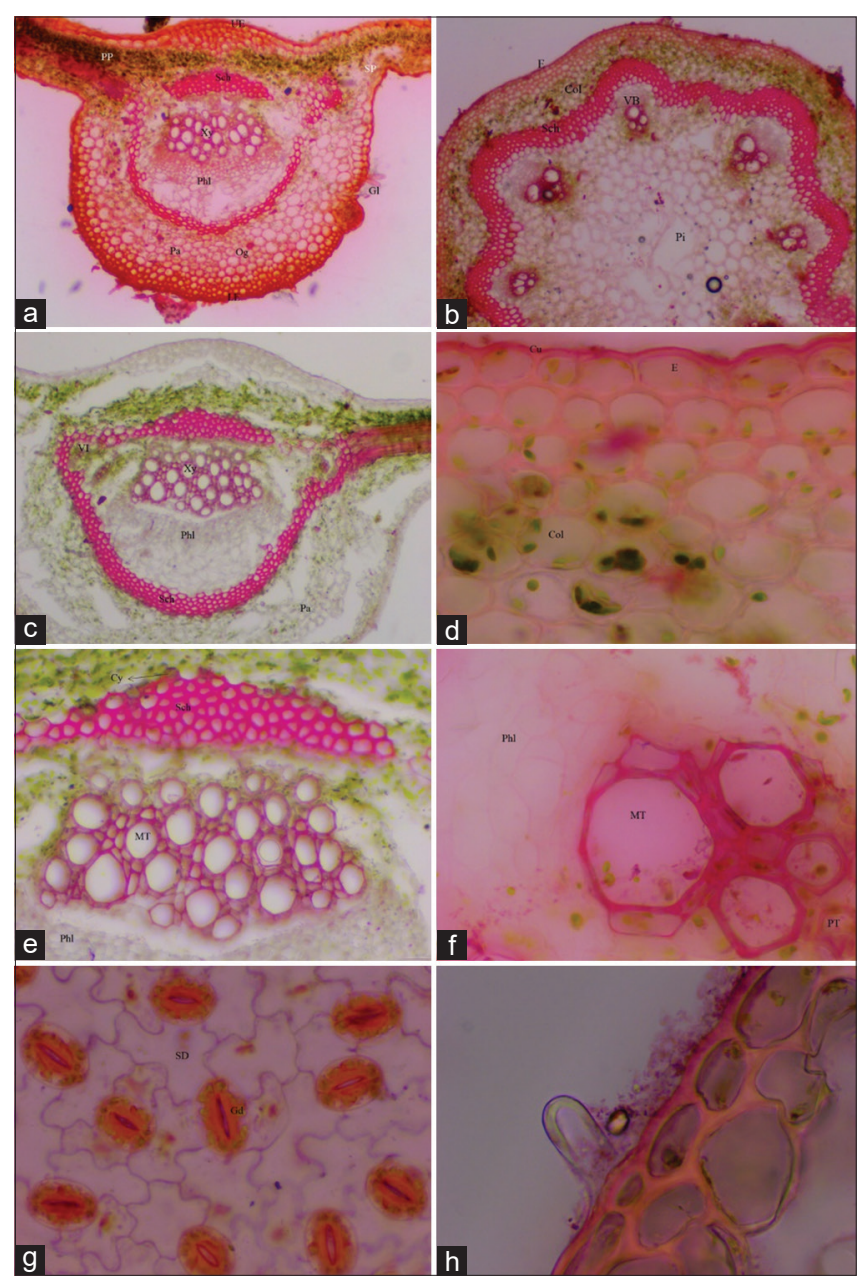

Figure 2: Transverse section of $T$. formanii Petiole and Leaf (a \& b) ground plan 4x; c - Leaf midrib vascular bundle 10x; d - Epidermis of petiole 40x; e - Metaxylem and Phloem 10x; $f$ - Petiole vascular bundle 40x; $g$ \& $h$ - Anomocytic and Paracytic stomata and nonglandular hair 40x; UE - Upper Epidermis; LE - Lower Epidermis; Col - Collenchyma; MT - Metaxylem; Pi - Pith; PT - Protoxylem; $\mathrm{Ph}$ - Phloem; Pa - Parenchyma; PP - Palisade Parenchyma; SD Subsidiary cells; GD - Guard cells; Scl - Sclerenchyma; Tr - Tracheid; VB - Vascular Bundle.

cortex consists of 20 to 25 layers of tangentially elongated parenchymatous cells, patches on some narrow-shaped stone cells and prism-shaped calcium oxalate crystals and the cells located towards inner side are polygonal in shape and filled with abundant oval and elliptic shape starch grains. Pericyclic cells are lignified fibers associated with a large number of prism-shaped crystals, broad and narrow shaped stone cells containing an outer layer towards the cortex. Stelar region is composed of discrete vascular strands with 8 major and 6 minor wedge-shaped strips of xylem, externally surrounded by circular strips of 10 layers of phloem on alternating, with wide medullary rays. The medullary rays are made up narrowshaped parenchymatous cells with simple starch grains. Cambium is composed of 2 to 3 layers of loosely arranged thin walled cells. Xylem consists of vessel elements, tracheid, parenchyma and fibers. Multilayered medullary rays filled with starch grains. Pith made up of 30 layers compactly 


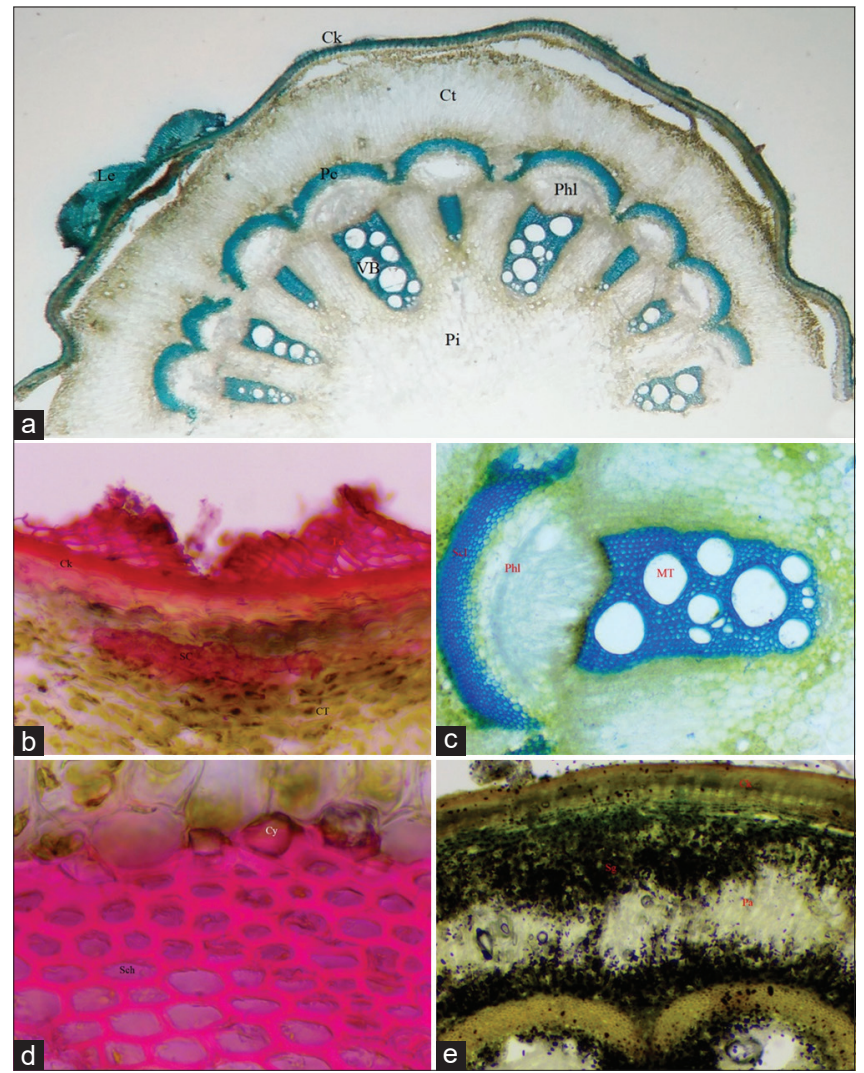

Figure 3: TS of the T. formanii stem a - Ground plan of the stem; $b-$ Enlarged view of the lenticels 10x; $c$ - Enlarged view of the single vascular bundles 10x; $d$-Enlarged view of the prismatic crystals $40 x$; e-Enlarged view of the abundant starch grains 10x; Le - Lenticels; Ck - Cork; Ct-Cortex; Cy -Crystals; MT - metaxylem; Pa-Parenchyma; $\mathrm{Pi}$ - Pith; Pc - Pericycle; Sc - Stone cells; Sg - Starch Grains; Scl Sclerenchyma; VB - Vascular Bundles.

arranged, large thin-walled parenchymatous cells containing simple, elliptical shaped abundant starch grains.

\section{Maceration Techniques}

Macerated stem shows scalariform pitted vessels, tracheid, xylem vessels with spiral thickening, fibers, prism-shaped calcium oxalate crystals and simple, oval to elliptical starch grains (Figure 4).

\section{Stomatal Index}

Stomata index was calculated on both leaf surfaces. Stomata index is more on the abaxial epidermis compared to the adaxial epidermis. It is stomatal number on the abaxial and adaxial side was found as 41 and 19, respectively and Stomatal Index of the abaxial and adaxial surface is 34.4 and 21.8 respectively.

\section{DISCUSSION}

T. cordifolia has an enormous importance in pharmacology. The species of Tinospora are widely distributed in the tropical and subtropical regions of India and China and have multiple
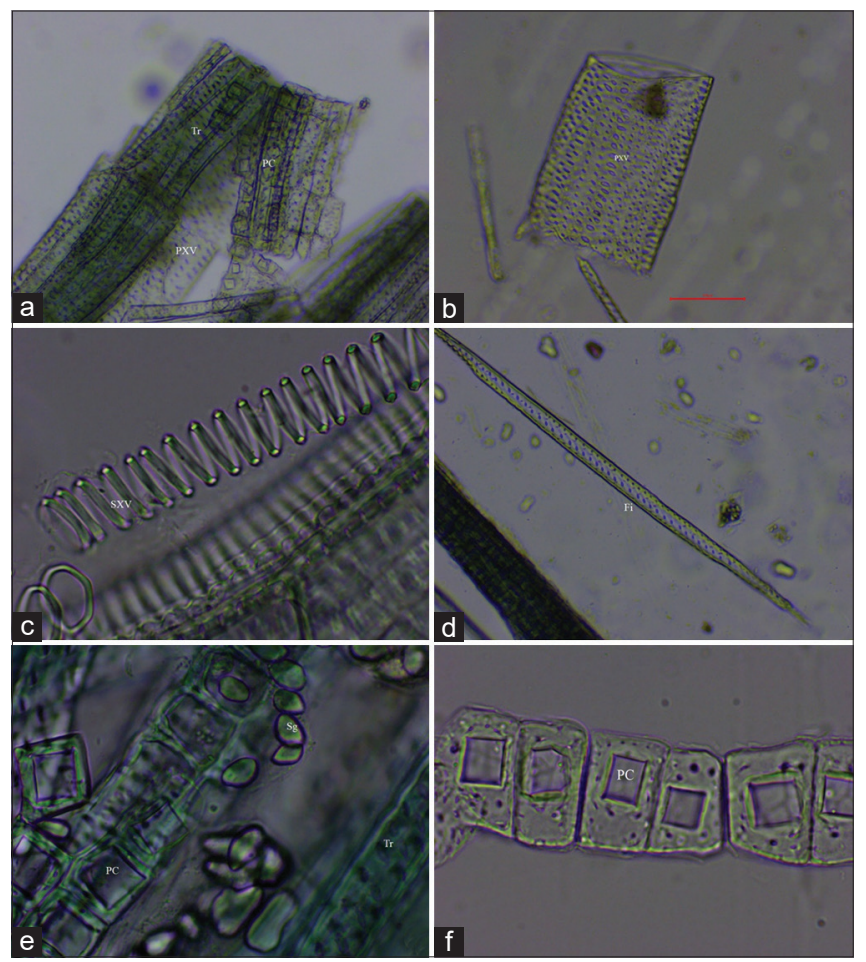

Figure 4: Macerated section of the T. formanii stem a - Xylem thickwalled cells $10 x ; b-$ Pitted xylem vessels $40 x ; c-$ Spiral xylem vessels 40x; $d$ - Xylem fiber 40x; e - Starch grains 40x; $f$ - Prism crystals 40x; Tr - Tracheid; PC - Prism Crystals; PXV - Pitted Xylem Vessels; SXV - Spiral Xylem Vessels; Fi - Fiber; Sg - Starch grains.

Table 1: Anatomical characters of T. formanii

\begin{tabular}{|c|c|c|}
\hline Characters & Leaves & Stem \\
\hline \multicolumn{3}{|c|}{ Macroscopic \& Organoleptic } \\
\hline Shape & $\begin{array}{l}\text { Ovate to elliptic- } \\
\text { lanceolate }\end{array}$ & Circular \\
\hline $\begin{array}{l}\text { Glands \& } \\
\text { Lenticels }\end{array}$ & $\begin{array}{l}\text { small elongated glands } \\
\text { in both surface }\end{array}$ & Lenticellate \\
\hline Powder colour & yellowish green & light brown \\
\hline Odour & Unpleasant & Unpleasant \\
\hline Taste & little bitter & No \\
\hline \multicolumn{3}{|l|}{ Microscopic } \\
\hline Epidermis/Bark & $\begin{array}{l}\text { Single layered in both } \\
\text { epidermis }\end{array}$ & Smooth, shining, papery \\
\hline Cortex & $\begin{array}{l}\text { Mesophyll cells in } \\
\text { lamina and Midrib } \\
\text { parenchyma and } \\
\text { collenchyma }\end{array}$ & $\begin{array}{l}20-25 \text { layers of tangentially } \\
\text { elongated parenchymatous } \\
\text { cells }\end{array}$ \\
\hline Vascular bundles & $\begin{array}{l}\text { Midrib vascular bundle } \\
\text { collateral and open }\end{array}$ & 8-9 collateral and open \\
\hline Pith & Absent & $\begin{array}{l}\text { Large compactly arranged, } \\
\text { thin walled parenchyma cells }\end{array}$ \\
\hline \multicolumn{3}{|l|}{ Histochemical } \\
\hline Starch Grains & Absent & Present \\
\hline $\begin{array}{l}\text { Calcium oxalate } \\
\text { crystals }\end{array}$ & Rosset & Prism-shaped \\
\hline Lignin & Absent & Present \\
\hline
\end{tabular}

applications in different folk medicine, including the Indian Ayurvedic System (Sadik et al., 2001; Ayyanar and Ignacimuthu, 2011; Sutar and Pal, 2015). Various studies including pharmacognostic, quantitative and qualitative analysis are available for these plants. Morphological and anatomical 
Table 2. Comparative stem anatomical characters

\begin{tabular}{|c|c|c|}
\hline Character & T. cordifolia & T. formanii \\
\hline Shape in TS & Wedge & Circular \\
\hline Bark & $\begin{array}{l}\text { Warty, glabrous with } \\
\text { round lenticels. }\end{array}$ & $\begin{array}{l}\text { Smooth, shining, papery, } \\
\text { several prominent } \\
\text { lenticellate. }\end{array}$ \\
\hline Cortex & $\begin{array}{l}\text { Cortex is } 15-22 \text { layers } \\
\text { parenchyma cells are } \\
\text { rounded and elongated } \\
\text { cells }\end{array}$ & $\begin{array}{l}\text { Cortex is } 20-25 \text { layers } \\
\text { of tangentially elongated } \\
\text { parenchymatous cells }\end{array}$ \\
\hline Pericycle & $\begin{array}{l}\text { Cap-like structure of 5-6 } \\
\text { layers of narrow pericycle } \\
\text { made from sclerenchyma } \\
\text { with lignified }\end{array}$ & $\begin{array}{l}\text { Cap-like structure of 6-8 } \\
\text { layers of tangentially } \\
\text { pericycle made from } \\
\text { sclerenchyma with lignified }\end{array}$ \\
\hline Secretory sac & Present & Present \\
\hline Vascular bundles & 5-7 collateral and open & 8-9 collateral and open \\
\hline Starch grains & $\begin{array}{l}\text { Present in cortical, } \\
\text { vascular bundles and pith }\end{array}$ & $\begin{array}{l}\text { present in cortical, vascular } \\
\text { bundles and pith }\end{array}$ \\
\hline Pith & $\begin{array}{l}\text { Large compactly } \\
\text { arranged, thin walled } \\
\text { parenchymatous cells }\end{array}$ & $\begin{array}{l}\text { Large compactly arranged, } \\
\text { thin walled parenchymatous } \\
\text { cells }\end{array}$ \\
\hline Crystals & Present & Present \\
\hline Source & $\begin{array}{l}\text { Bonde \& Upaehye, 1989; } \\
\text { Nasreen et al., } 2010\end{array}$ & Current work \\
\hline
\end{tabular}

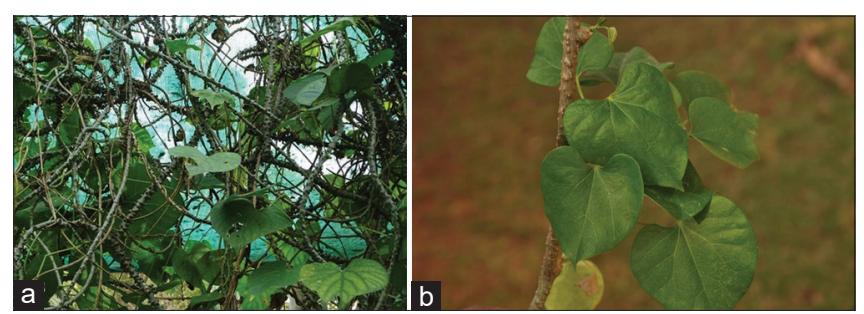

Figure 5: Filed vegetative images of a. T. crispa (L.) Miers. ex Hook. f. and Thomson \& b. T. cordiflolia (Willd.) Miers. ex Hook. f. and Thomson.

studies have shown the distinctive and differentiating characters between Tinospora species. Metcalfe and Chalk (1950) reported Ranunculaceous (Anomocytic) stomata in Menispermaceae. Similarly, in the present study our observations on Anomocytic and Paracytic stomata, non-glandular hairs with T. formanii leaf. Tinospora species stem and leaf macro-microscopic diagnostic key characters as descried in earlier studies viz., Tinospora cordifolia, T. sinensis and T. crispa appear similar in external morphological characters by having broadly cordate leaves, cylindrical twining stems, often lenticels and aerial adventitious roots. T. cordifolia stem cylindrical, slender, wedge shaped and 5-7 vascular bundles. T. sinensis stem, circular outline and most abundant in unicellular trichome, 5-8 vascular bundles and T. crispa stem circular in outline, 5-7 vascular bundles (Begum et al., 2019; Parveen et al., 2020). The study has been undertaken to differentiate and standardize T. formanii with that of T. cordifolia. Stems anatomical characters of both these species have been provided in detail (Table 2) along with morphological comparative characters of T. crispa and T. cordifolia (Figure 5).

\section{CONCLUSION}

This type of anatomical studies will help to establish identity, purity, quality and safety of the drug for various pharmaceutical industries in the preparation of AYUSH medicines when a drug is admixed with other species of Tinospora and it is helpful to research scholars, students in carrying out further research studies for further establishment of different species of Tinospora; wherever is a very important drug in the indigenous system of medicine for further documentation of research studies.

\section{ACKNOWLEDGEMENTS}

The authors are thankful to Shri. Darshan Shankar, Vice Chancellor, FRLHT-TDU, Bangalore for providing facilities, constant support and encouragements. Special thanks are due to Dr. P. Ravichandran, Professor \& Head, Dept. of Plant Science, MS University, Tirunelveli, Tamil Nadu and Dr. T. R. Shantha, Research Officer (Retired), RARIMD, Bengaluru, Karnataka for organizing this paper and providing valuable suggestions for the anatomical studies. Thanks to Dr. S. Gokul, Research Associate, FRLHT-TDU for meticulously setting the photo plates.

\section{REFERENCES}

Ahmad, I., Aqil, F., \& Owais, M. (2006). Modern phytomedicine: Turning medicinal plants into drugs. $\left(1^{\text {st }}\right.$ ed). John Wiley \& Sons.

Ayyanar, M., \& Ignacimuthu, S. (2011). Ethnobotanical survey of medicinal plants commonly used by Kani tribals in Tirunelveli hills of Western Ghats, India. Journal of Ethnopharmacology. 134(3), 851-864. https:// doi.org/10.1016/j.jep.2011.01.029

Begum, N. S., Patturaj, R., \& Ravikumar, K. (2019). Comparative pharmacognostical and histochemical studies on the three different species of Tinospora on stem and leaf. Journal of Pharmacognosy and Phytochemistry, 8, 650-655.

Bonde, S. D., \& Upaehye, A. S. (1989). Contribution to the wood anatomy of Tinospora sinensis (Lour) Merrill in relation with T. cordifolia Miers. Ancient Science of Life, 9(2), 80-85.

Chamberlain, C. J. (1924). Methods in plant histology. (4 ${ }^{\text {th }}$ Eds.) Chigago, University of Chicago Press.

Forman, L. L. (1981). A revision of Tinospora (Menispermaceae) in Asia to Australia and the Pacific: The Menispermaceae of Malesia and adjacent areas. X. Kew Bulletin, 375-421. https://doi. org/10.2307/4113613

Jeffrey, E. C. (1917). The anatomy of woody plants. (3 ${ }^{\text {rd }}$ edition). Chicago, University of Chicago Press.

Johansen, D. A. (1940). Plant microtechnique. (1 ${ }^{\text {st }}$ edition). New York. McGraw-Hill Book Company.

Kamboj, V. P. (2000). Herbal Medicine. Current Science, 78, 35-39.

Krishnamurthy, K. V. (1988). Methods in plant histochemistry. Madras: $S$ Viswanathan Printers and Publishers private limited.

Mabberley, D. J. (1997). The Plant-Book: A portable dictionary of the vascular plants. ( $2^{\text {nd }}$ ed). Cambridge university press.

Metcalf, C. R., \& Chalk, L. (1950). Anatomy of dicotyledons, Vol I. Clarendon Press, Oxford

Nasreen, S., Radha, R., Jayashree, N., Selvaraj., \& Rajendran, A. (2010). Assessment of quality of Tinospora cordifolia (WILLD.) MIERS (Menispermaceae): Pharmacognostical and Phyto-physicochemical profile. Pharmacie Globale, 5(03), 1-4.

Odugbemi, T. (2008). A textbook of medicinal plants from Nigeria. University of Lagos Press.

Parveen, A., Adams, J. S., Raman, V., Budel, J. M., Zhao, J., Babu, G., Ali, Z., \& Khan, I. A. (2020). Comparative morpho-anatomical and HPTLC profiling of Tinospora species and dietary supplements. Planta Medica, 86(7), 470-481. https://doi.org/10.1055/a-1120-3711

Pramanik, A., \& Gangopadhyay, M. (1993). Menispermaceae. In, B. D. Sharma, N. P., Balakrishnan, R. R. Rao, \& P. K. Hajra, (Eds.), Flora of India I. Calcutta; Botanical Survey of India.

Rohwer, J. G., \& Bittrich, V. (1990). The families and genera of vascular plants. Kubitzki, K. editor. Berlin: Springer. https://doi. org/10.1007/978-3-662-07255-4. 
Ruthmann, A. C. (1970). Methods in cell Research. Ithaca, New York: Cornell University Press.

Sadik, G., Gafur, M. A., Bhuiyan, M. S. A., Alam, A. H. M., K., M., Biswas, H. U., Hassan, P., Mannan, M. A., Khan, O. F., \& Chowdhury, A. K. A. (2001). Antifertility activity of Pergularia daemia. Journal of Medical Sciences, 1(1), 22-24.

Saleem, T. M., Christina, A. J., Chidambaranathan, N., Ravi, V., \& Gauthaman, K. (2008). Hepatoprotective activity of Annona squamosa Linn. on experimental animal model. International Journal of Applied Research in Natural Products, 1(3), 1-7.

Sheema, D. P., Najla, M., Swetha, E. S., Udayan, P. S., \& Elyas, K. K. (2017). Callus induction and organogenesis from Tinospora formanii Udayan and Pradeep: A rare endemic plant. Tropical Plant Research, 4(1), 71-76. https://doi.org/10.22271/tpr. 2017.v4.11.010

Shrestha, P. M., \& Dhillion, S. S. (2003). Medicinal plant diversity and use in the highlands of Dolakha district, Nepal. Journal of Ethnopharmacology, 86(1), 81-96. https://doi.org/10.1016/S03788741(03)00051-5

Sutar, N. G., \& Pal, S. C. (2015). Finger printing analysis of the flavonoid from leaves Pergularia daemia Forsk using HPTLC analysis. Journal of Pharmacognosy Phytochemistry, 3(5), 157-161.

Udayan, P. S., Pradeep, A. K., \& Balachandran, I. (2009). A new species of Tinospora (Menispermaceae) from South India. Edinburgh Journal of Botany, 66(1), 77-80. https://doi.org/10.1017/S0960428609005204 